\title{
Population structure and reproductive behavior of Sinaloa cichlid Cichlasoma beani (Jordan, 1889) in a tropical reservoir
}

\author{
Melgen A. García-Lizárraga ${ }^{1}$, Francisco Enrique Soto-Francooㅣㄹ Javier Marcial de Jesús \\ Ruiz Velazco-Arce², José Iván Velázquez-Abunader³, Jorge Saúl Ramírez-Pérez ${ }^{1,3}$ and \\ Emilio Peña-Messina
}

\begin{abstract}
The population structure and reproductive condition of the Sinaloa cichlid Cichlasoma beani from samples obtained from June 2000 to July 2001 were determined. Samples in the first week each month from the largest trader of tilapia in the Aguamilpa Reservoir in Mexico and were caught in gillnets (9.6 and $11.4 \mathrm{~cm}$ stretch-mesh size). Of 596 specimens, there were 427 males and 169 females; monthly sex ratio, frequency of lengths by the multinomial distribution, timing of reproduction, condition index, and size at first maturity was determined. Differences in the sex ratio and monthly totals were significant, favoring males, except for September 2000 and March 2001. From one (August 2000) to three modal groups (July 2000 and June 2001) were identified by size. There were no significant differences in standard length weight relationships by sex, which indicated that a shared model for both genders is appropriate, and isometric growth was detected. Based on the proportion of mature and partially matures fish, the main reproductive period was April through June; size at first maturity was $18.9 \mathrm{~cm}$. Water temperature was not significantly related to the percentage of mature and partially matures Sinaloa cichlids or spawning. These findings provide information for regulating the Cichlasoma beani fishery in this region such minimum legal size and non-fishing period.
\end{abstract}

Se determinó la estructura poblacional y condición reproductiva del cíclido de Sinaloa Cichlasoma beani desde junio de 2000 a julio de 2001. Las muestras se obtuvieron de la captura comercial de tilapia en el embalse de Aguamilpa, México durante la primera semana de cada mes. Los especímenes se capturaron con redes de enmalle (9,6 y 11,4 cm de tamaño de malla). De los 596 organismos recolectados, 427 fueron machos y 169 hembras. Se determinó la proporción de sexos mensual, grupos modales de tallas a través de una distribución multinomial, época reproductiva, índice de condición y talla de primera madurez. Se encontraron diferencias significativas en la proporción de sexos total y mensual favoreciendo a los machos, excepto en septiembre de 2000 y marzo de 2001. Se identificaron desde uno (agosto de 2000) hasta tres grupos modales de tallas (julio de 2000 y junio de 2001). No se encontraron diferencias significativas en la relación longitud patrón - peso total por sexo, lo que sugiere que el uso de un solo modelo para ambos sexos es adecuado, presentando crecimiento de tipo isométrico. Con base en la proporción de organismos parcialmente maduros y maduros, el pico principal de reproducción fue desde abril hasta junio; la talla de primera madurez fue de $18,9 \mathrm{~cm}$. No se encontró una correlación significativa entre la temperatura del agua y el porcentaje de individuos parcialmente maduros, maduros o desovados. La información generada es útil para la regulación de la pesca de Cichlasoma beani en esta región, sugiriendo una talla mínima legal de captura y un periodo de veda adecuado para la especie.

Key words: Cichlidae, Condition index, Length at maturity, Length frequency, Reproduction.

\footnotetext{
${ }^{1}$ Universidad Autónoma de Sinaloa, Facultad de Ciencias del Mar, Paseo Claussen s/n Col. Los Pinos, Mazatlán, Sinaloa 82000, Mexico. ${ }^{2}$ Universidad Autónoma de Nayarit, Dirección de Fortalecimiento de la Investigación . Cd. de la Cultura Amado Nervo s/n Tepic, Nayarit 63255, Mexico. Corresponding author: marcialj@nayar.uan.mx

${ }^{3}$ Departamento de Pesquerías y Biología Marina, Centro Interdisciplinario de Ciencias Marinas (CICIMAR-IPN), Av. Instituto Politécnico Nacional s/n, Col. Playa Palo de Santa Rita, La Paz, B.C.S. 23096, Mexico.
} 


\section{Introduction}

Native cichlids comprise $\sim 50 \%$ of the fish in freshwater lakes and reservoirs in Central America; about $60 \%$ belong to the genus Cichlasoma (Miller, 1966) and life cycle studies of this species have serious restrictions mainly because they have high value for the local fisheries and have been introduced to many water bodies (Luna-Figueroa \& FigueroaTorres, 1999).

Aguamilpa Reservoir on the río Santiago (10,000 ha) was built in the late 1980 s to generate electricity and to provide irrigation and flood control in the central part of the state of Nayarit (Orbe-Mendoza et al., 2002). Commercial fishing in the reservoir started in the 1990s, benefiting 5,400 inhabitants in local communities, mostly indigenous people living in villages near the reservoir (SAGARPA, 2006). Capture statistics indicate a sharp increase in fish production from 1995 to 2000, reaching $\sim 5,000 \mathrm{t}$, making it the most productive reservoir in Mexico (SAGARPA, 2006). Since 2007, commercial fishing has been prohibited from March through May (DOF, 2007) because the managers believe that the majority of fish species that inhabit Aguamilpa Reservoir spawn during this time. However, establishment of this non-fishing period apparently did not favor recovery of the population of $C$. beani, based on observations of fishermen that there is a decline of this species in commercial catches. There are no records of abundance estimates of $C$. beani in Aguamilpa Reservoir because they are neither officially recorded harvest data of commercial catches or for the Sinaloa cichlid.

Pérez-Velázquez et al. (2005) states that the target species in the reservoir's fishery is the blue tilapia Oreochromis aureus, but production also includes bass (Micropterus salmoides), carp (Cyprinus carpio), catfish (Ictalurus punctatus), chihuil (Ictalurus sp.), and Sinaloa cichlid (Cichlasoma beani). Despite their economic importance, knowledge of their biology and ecology of some of these species is minimal, as is the case of the small Sinaloa cichlid, which is mainly sold and consumed locally. To date, there are no specific measures to regulate this resource.

For different species of the family Cichlidae, there have been studies of reproductive traits (Duponchelle et al., 1999; Gomez-Marquez et al., 2003; Komolafe \& Arawomo, 2007), growth (Getabu, 1992; Booth \& Merron, 1996; Admassu \& Casselman, 2000; Caskey et al., 2007; Bwanika et al., 2007; Gomez-Marquez et al., 2008), and aspects of the fishery (Balirwa, 1992; Jiménez-Badillo, 2004). There is no study of population structure and reproductive maturity by $C$. beani.

Here, we determined important biological parameters for understanding the Cichlasoma beani fishery, such as size structure, reproductive behavior, and its relationship to water temperature. We intend to use this knowledge to establish regulations for harvesting.

\section{Material and Methods}

\section{Collection of specimens}

We obtained random samples in the first week of each month from local fishermen of their catches from July 2000 through June 2001 at landing sites around Aguamilpa Reservoir (21 $1^{\circ} 53^{\prime} 21^{\circ} 23^{\prime} \mathrm{N}, 104^{\circ} 46^{\prime} 104^{\circ} 25^{\prime} \mathrm{W}$; Fig. 1). In this twelve months, we examined 596 Sinaloa cichlids that were caught in gillnets (9.6 and $11.4 \mathrm{~cm}$ stretch-mesh size), which are placed at sunset and collected at dawn. Monthly sample sizes varied according to the volume of the landed catch. Standard length $(\mathrm{SL} \pm 0.1 \mathrm{~cm})$ and total weight $(\mathrm{TW} \pm 0.1 \mathrm{~g})$ were measured and the gender of each specimen was recorded. Surface water temperature in the reservoir was obtained with a bucket thermometer $\left( \pm 0.1{ }^{\circ} \mathrm{C}\right)$. Voucher specimens were deposited in the fish collection of Escuela Nacional de Ingeniería Pesquera, Universidad Autónoma de Nayarit, Mexico (ENIP-CI-41).

\section{Population features}

From monthly and total sex ratios, $\chi^{2}$ analysis tested the null hypothesis that males and females were equally common. Monthly size frequency was grouped into $1 \mathrm{~cm}$ SL class intervals. Size structure between males and females was assessed with the Kolmogorov-Smirnov test for two independent samples.

A modal progression analysis was determined for trends in the monthly size frequencies using a multinomial distribution (Haddon, 2001) described by Aguirre-Villaseñor et al. (2006), given by the following probability density function:

$$
P\left\{x_{i} \mid n, p_{1}, p_{2}, \ldots, p_{k}\right\}=n ! \prod_{i=1}^{k} \frac{p_{i}^{x_{i}}}{x_{i} !},
$$

where $x_{i}$ is the number of times that a $i$-type event occurs in $n$ samples and $p_{i}$ are the separate probabilities of each one of the possible $k$-type events. Estimation of model parameters was performed by transforming the above equation and minimizing it:

$$
-\ln L\left\{x_{i} \mid n, p_{1}, p_{2}, \ldots, p_{k}\right\}=\sum_{i=1}^{n}\left[x_{i} \ln (p)\right] .
$$

An important assumption of this technique is that the size distribution and average length can be treated, based on a normal distribution and each mode can be interpreted as a cohort (Fournier et al., 1990; Aguirre-Villaseñor et al., 2006). Accordingly, we assume that $p$ follows a normal distribution in each cohort so the estimates of the expected relative proportions of each modal group were described, based on the following probability density function:

$$
P_{L_{k}}=\frac{1}{\sigma_{n} \sqrt{2 \pi}} e^{\frac{-\left(L_{k}-\mu_{n}\right)^{2}}{2 \sigma_{n}}},
$$


where $\mu$ and $\sigma$ are the mean and standard deviation of standard length for each cohort. To estimate expected frequencies and estimate the model parameters, we compared the observed and estimated values by the logarithmic function of the multinomial distribution with the following equation (Haddon, 2001):

$$
-\ln L\left\{L \mid \mu_{n}, \sigma_{n}\right\}=-\sum_{i=1}^{n} L_{i} \ln (\hat{p})=-\sum_{i=1}^{k} L_{i} \ln \left(\frac{\hat{L}_{i}}{\sum \hat{L}_{i}}\right) .
$$

This function was minimized by the Newton algorithm.

\section{Relationship between standard length and total weight}

The standard length (SL) to total weight (TW) relationship was determined for females, males, and total number by the power model $T W=a S L^{b}$ (Ricker, 1975). The parameters were obtained by transforming the linear regression equation $\log T W=\log a+(\log S L) b$, where $a$ is a constant and $b$ is the slope. The value of parameter $b$ was compared with $b=3$ (isometry) by Student's $t$-test (Sokal $\&$ Rohlf, 1979). To compare sex models, slopes and elevations were determined using covariant analysis (ANCOVA; Zar, 2010).

\section{Analysis of reproductive conditions}

We assigned maturity status according to criteria of Nikolsky (1963) and Rojas-Carrillo (2006) to all females, based mainly on six phases defined by size, color, and texture of the gonads: I (immature), II (repose), III (development), IV (partially mature), V (mature), and VI (Spawning). To determine is there is a correlation between water temperature and percentage of Stage IV and Stage V, a nonparametric rank correlation of the Spearman analysis $\left(r_{s}\right)$ was used with arcsine transformation of percentages. To determine physical condition over time, we calculated the monthly relative condition factor $\left(K_{n}\right)$ described in Le Cren (1951):

$$
K_{n}=\frac{W T_{o}}{W T_{e}}
$$

where $W T_{o}$ is the total weight of each fish and $W T_{e}$ is the total weight calculated by the power model of standard length to total weight (SL-TW). The average monthly value of $K_{n}$ with the monthly frequency of Stages IV and V were analyzed. The size at first maturity was considered the length when $50 \%$ of females at Stages IV and V from the cumulative relative frequency of females at these stages were fitted to the logistic model in Sparre \& Venema (1997) according to:

$$
P=\frac{1}{1+e^{(a-b S L)}},
$$

where $P$ is the proportion of mature fish defined by length interval and $a$ and $b$ are model parameters. Once fitted, the size at first maturity (the length at which $50 \%$ of the fish are reproducing, $L_{m} 50 \%$ ) was calculated as $L_{m} 50 \%=a / b$.

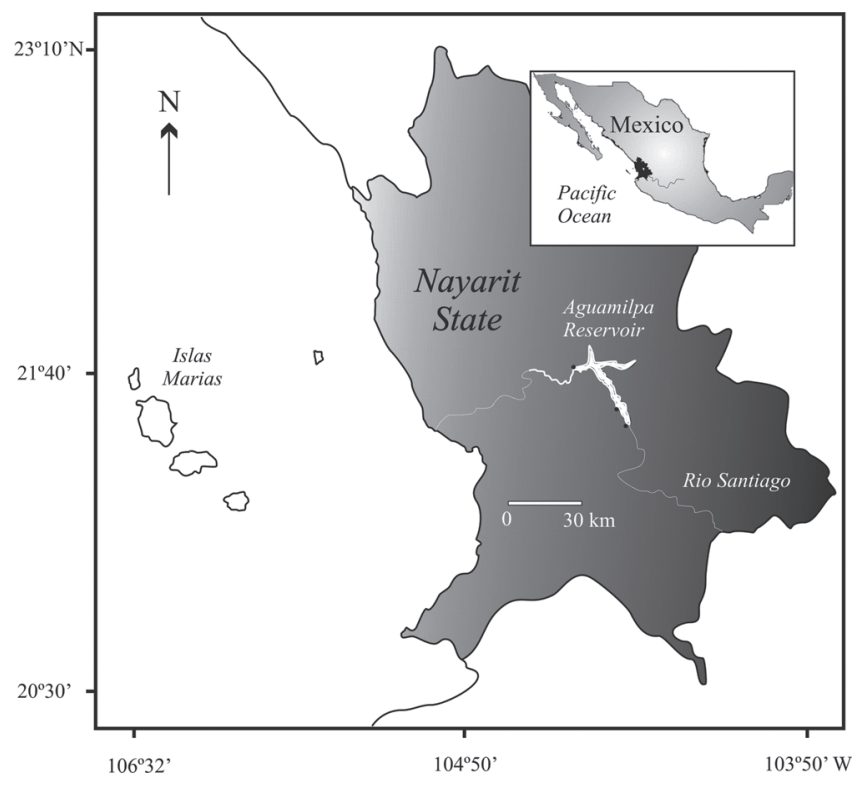

Fig. 1. Aguamilpa Reservoir, Nayarit, Mexico. Black dots indicate landing sites and sampling areas.

\section{Results}

\section{Population features}

During the survery, we examined 596 specimens ( 427 males and 169 females). The total sex ratio was significantly different from 1:1 ( 1 female:2.56 males; $\chi^{2}, \mathrm{p}<0.0001$ ). Monthly sex ratios were dominated by males except September 2000 and March 2001 , when the proportion was close to $1: 1\left(\chi^{2}, p>0.05\right.$; Fig. 2a). Most females were 18 to $20 \mathrm{~cm} \mathrm{SL}$ and most males were 20 to $22 \mathrm{~cm} \mathrm{SL}$; significant differences in size of females and males were detected (K-S, p < 0.05; Fig. 2b). The SL range in males was $10-30 \mathrm{~cm}$ with a mean of $18.89 \mathrm{~cm}(\mathrm{SD}=3.46 \mathrm{~cm})$. The SL range in females was $10.5-30 \mathrm{~cm}$ with a mean of $18.85 \mathrm{~cm}(\mathrm{SD}=$ $3.44 \mathrm{~cm})$. The smallest fish were captured in February $(11.5 \mathrm{~cm})$, May (11 cm), and June $2001(10.5 \mathrm{~cm})$ and the largest in July (30 $\mathrm{cm})$ and August $2000(29.9 \mathrm{~cm})$. Table 1 shows that in most months there were two modal groups except June 2001, when three modal groups occurred, and in August 2000 and April 2001 with there was one modal group (Fig. 3).

\section{Relationship between standard length and total weight}

No significant differences between males and females were found in the power models constructed from the SL-TW relationship (ANCOVA, $\mathrm{p}>0.05$ ); therefore, a shared model was constructed. The slope of the above power model $(b=2.87)$ was not statistically different from the hypothetical value of 3 (Student's $t$-test, $p>0.05$ ) to detect isometric growth (Fig. 4).

\section{Reproductive features}

Although percentage of reproductively active individuals was always $<25 \%$, there were two peaks: the months of winter and summer (Fig. 5). The correlation between percent of ripe 


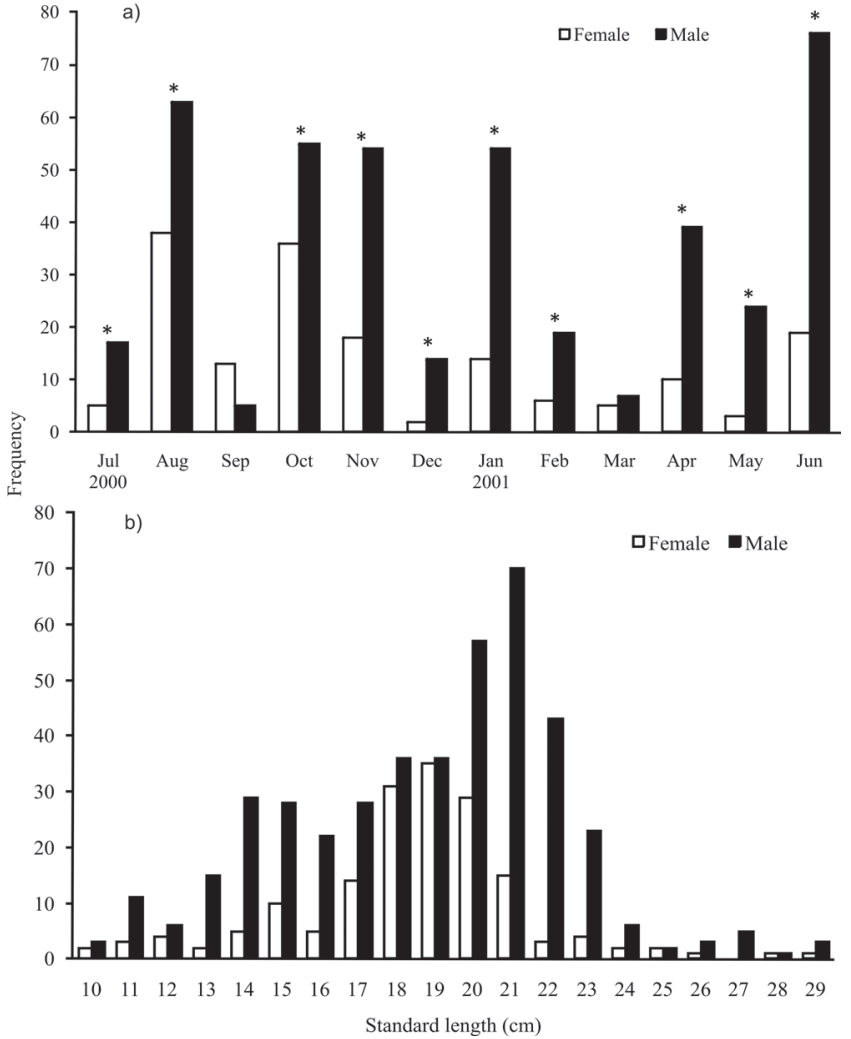

Fig. 2. (a) Monthy sex ratio; (b) Length-frequency distribution by gender for Sinaloa cichlid Cichlasoma beani in the Aguamilpa Reservoir in Mexico. Asterisks indicate significant differences.

individuals and water temperature was not significant $\left(\mathrm{r}_{\mathrm{s}}=\right.$ $0.021, p>0.05)$ and there was no detected correlation between spawning individuals and temperature $\left(\mathrm{r}_{\mathrm{s}}=-0.27, \mathrm{p}>0.05\right)$.

Relative condition was highest during December 2000 January 2001, which coincide when there were more percentage of females at Stages IV and V and the average water temperature was $<26^{\circ} \mathrm{C}$ (Fig. 6a). Relative condition was the lowest during March when the proportion of sexually mature individuals was increasing and water temperature began to increase in the early spring (Fig. 6b).

Size at first maturity $\left(L_{m} 50 \%\right)$ was $18.6 \mathrm{~cm} \mathrm{SL}$, based on the logistic model (Fig.7); the smallest fish showing reproductive activity was $10.5 \mathrm{~cm} \mathrm{SL}$.

\section{Discussion}

In the Aguamilpa Reservoir, dominance of males over females in most months probably results from spatial segregation. Similar results in African lakes were reported by Fryer (1972), concluding that this is common in populations of cichlids and there was no risk in the fishery. Some authors suggest clear differences in the sex ratio are common among the Cichlidae, for example, Ramos-Cruz (1995) found that male Oreochromis aureus in the Benito Juárez Reservoir accounted for $72.2 \%$ of the population and Biotecs (1990) reports that
Table 1. Mean \pm SD of the standard length of modal group estimates by month for the Sinaloa cichlid Cichlasoma beani in the Aguamilpa Reservoir.

\begin{tabular}{llll}
\hline Month & \multicolumn{3}{c}{ Modal groups $(\mathrm{cm})$} \\
\hline July 2000 & $13.0 \pm 1.0$ & $19.0 \pm 1.1$ & $27.0 \pm 4.9$ \\
August & & $19.9 \pm 1.1$ & \\
September & & $18.3 \pm 0.9$ & $26.7 \pm 0.1$ \\
October & $20.2 \pm 1.8$ & $28.4 \pm 0.1$ \\
November & & $18.3 \pm 1.2$ & $21.1 \pm 0.8$ \\
December & & $18.8 \pm 1.4$ & $22.6 \pm 0.2$ \\
January 2001 & $16.4 \pm 1.0$ & $19.9 \pm 1.1$ & \\
February & $12.0 \pm 0.6$ & $20.5 \pm 1.5$ & \\
March & $14.5 \pm 0.3$ & $20.3 \pm 1.1$ & \\
April & $15.0 \pm 1.2$ & $20.9 \pm 2.0$ & \\
May & $16.1 \pm 1.7$ & & \\
June & $11.0 \pm 1.0$ & $14.0 \pm 1.0$ & $18.0 \pm 1.0$ \\
\hline
\end{tabular}
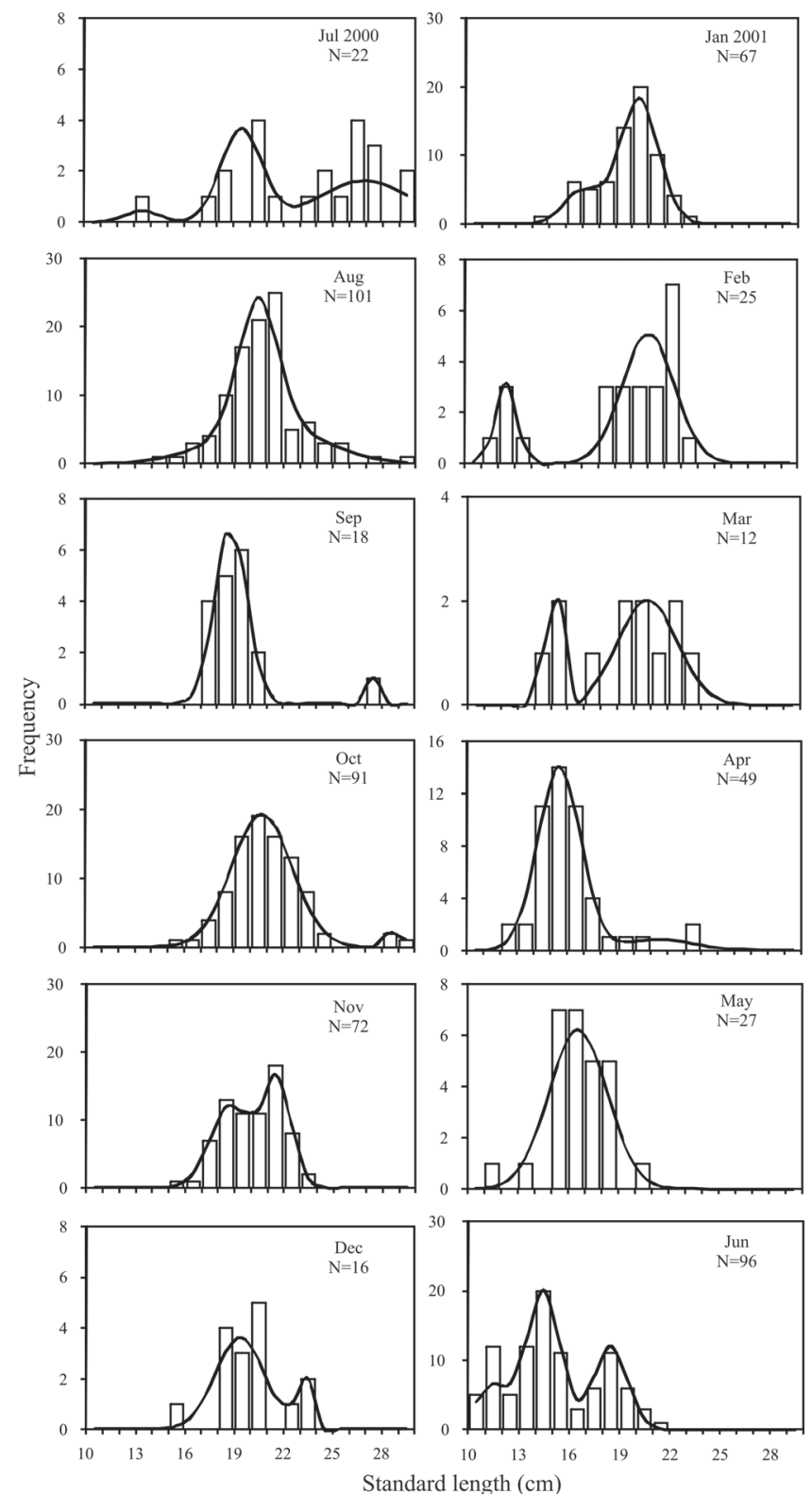

Fig. 3. Monthly frequency distribution of size and modal groups of Sinaloa cichlid Cichlasoma beani in the Aguamilpa Reservoir in Nayarit, Mexico. 


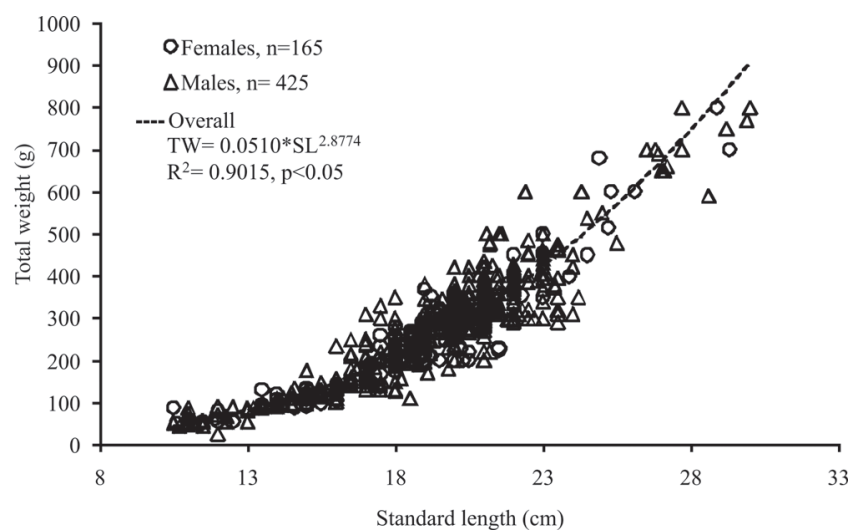

Fig. 4. Relationship between standard length and total weight (SL-TW) of the Sinaloa cichlid Cichlasoma beani in the Aguamilpa Reservoir in Nayarit, Mexico.

males of that species accounted for $67 \%$ of the population in the Temazcal Reservoir. According to other authors, in lakes and reservoirs of Mexico and Nigeria, male of $O$. niloticus represent $\sim 50 \%$ of the populations (Gomez-Marquez et al., 2003; Komolafe \& Arawomo, 2007). In the Aguamilpa Reservoir, temperature is largely dependent on water depth and quantity of water withdrawn for domestic and agricultural purposes. In the time to our survey, lower water volumes were reported $\left(<4000 \mathrm{~m}^{3}\right)$, which decreased the depth of the reservoir (Rangel-Peraza et al., 2009). These changes in the reservoir could affect the growth and period of reproduction (Wantzen et al., 2008).

Obtaining accurate values for the relationship between length and weight is important because estimates of biomass made with analytical models, such as a virtual population, requires average weight of individuals (Frota et al., 2004), which is easily obtained if one has the $a$ and $b$ values of this relationship. The SL-TW relationship indicated that the Sinaloa cichlid has isometric growth because the value of $b$ (2.87) did not differ statistically from the theoretical value $(b=$ 3 ) and differs from allometric growth for cichlid species found in other reservoirs and lakes (Ramos-Cruz, 1995; Fonticiella, 2000; Khallaf et al., 2003; Gomez-Marquez et al., 2008). The above differences in species of the Cichlidae are attributed to eating problems, density of fish, and environmental conditions (Murphy et al., 1991). Ibáñez (2004) suggests that variations in allometry of tilapias $O$. aureus and $O$. niloticus result from seasonal environmental changes and is also affected by maturity of the gonads. The reproductive process increases body weight without necessarily reflecting suitable physical condition; therefore, an index may be necessary to assess the condition of the fish and the condition index of Le Cren (1951) is useful to evaluate the condition in Sinaloa cichlid.

The dominance of individuals of 18-22 cm SL in the catches could be influenced by selectivity of the fishing gear, although few of smaller sizes were caught. The gillnets that are used are not built to the specifications listed in the government regulations (NOM-026-PESC-1999; DOF, 2000)

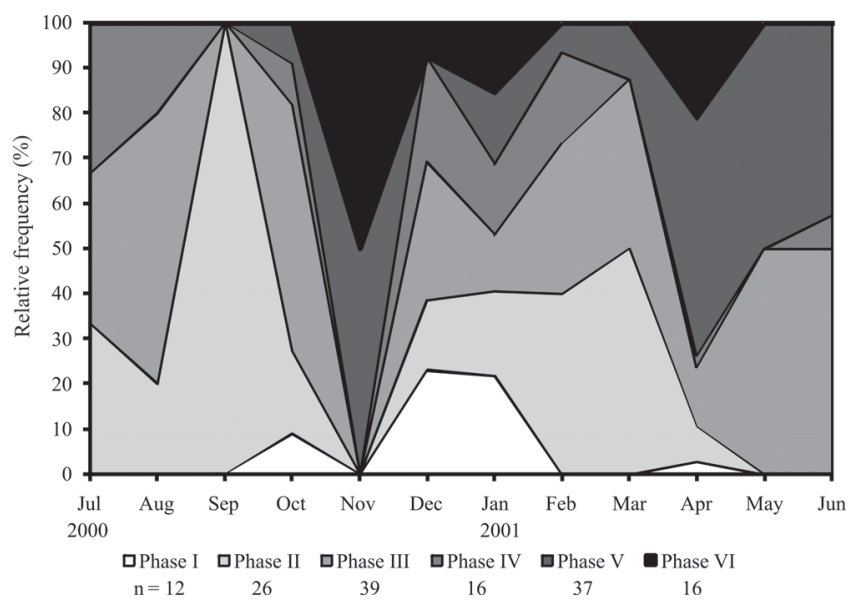

Fig. 5. Reproductive cycle of the Sinaloa cichlid Cichlasoma beani in the Aguamilpa Reservoir in Nayarit, Mexico.

for the exploitation of fisheries resources in the Aguamilpa Reservoir. Multinomial distribution, an extension of a binomial distribution, is applicable in situations where there are more than two possible outcomes from an observation. In this case, the model predicts the relative abundance of each age group (cohort) and these can be combined to produce data on catch at age by the splitting of the size frequency distributions into modal groups (Haddon, 2001; Aguirre-Villaseñor et al., 2006). Based on this modeling, we detected three age groups of Sinaloa cichlids; however, validating these modal groups in future studies by direct methods (otoliths and scales) are necessary before they can be considered as age groups. Using direct methods, Faunce et al. (2002) detected up to seven age groups for $C$. urophthalmus, Booth \& Merron (1996) detected eleven age groups for O. macrochir and ten for $O$. aureus in the Infiernillo Reservoir, using indirect methods, and Ibáñez (2004) identified two modal groups in the Lago Metztitlán for O. aureus and O. niloticus. Therefore, it is common to find multiple cohorts in cichlid species in different water bodies.

The proportion of females was low, with ripe females, $<25 \%$ of the total sample. The two peak periods of spawning occurred during the open catch season in the reservoir, which is regulated by the federal government (DOF, 2007). In our survey, there was no significant correlation between water temperature and percentage of ripe females, but this may be masked by the low proportion of females at this stage. In the Aguamilpa Reservoir, Peña-Messina et al. (2010) report a significant correlation between temperature and reproductive event of tilapia $O$. aureus, finding the peak of reproductive activity when temperatures were $25-28.3{ }^{\circ} \mathrm{C}$; however, the impact of temperature on reproductive condition in $C$. beani was not clear. Apparently, this environmental variable does not determine reproduction this species in the study zone, but the high percentages of individuals in Stages IV and V collected from November through June coincided with periods of higher average 


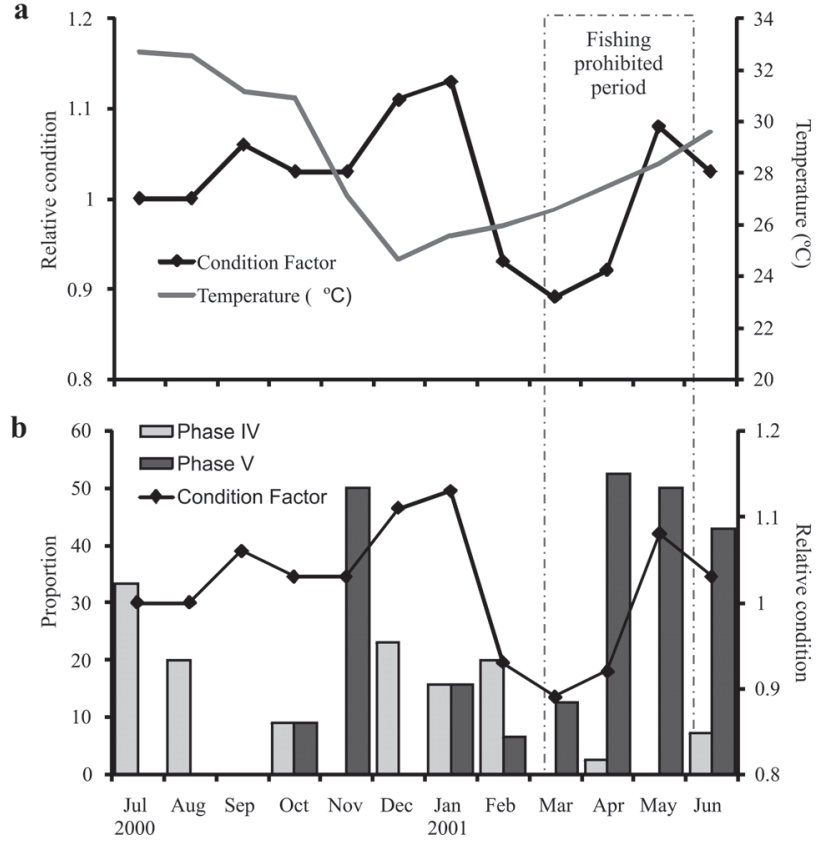

Fig. 6. (a) Relationship between relative condition index and surface temperature; (b) Relationship of condition index and percentage of Sinaloa cichlid Cichlasoma beani females in Stages IV and V of the maturity scale of Nikolsky (1963) in the Aguamilpa Reservoir, Mexico.

concentration of dissolved oxygen (Rangel-Peraza et al., 2009), while the rainy season (August through October) is not apparently conducive to spawning in $C$. beani. Future studies to address the relationship between these environmental variables and reproductive events of this species are necessary. Among the females, $36 \%$ were smaller than the size at first maturity. This has a negative impact in the Sinaloa cichlid because, if this is the case, it would not allow satisfactory recovery of population levels.

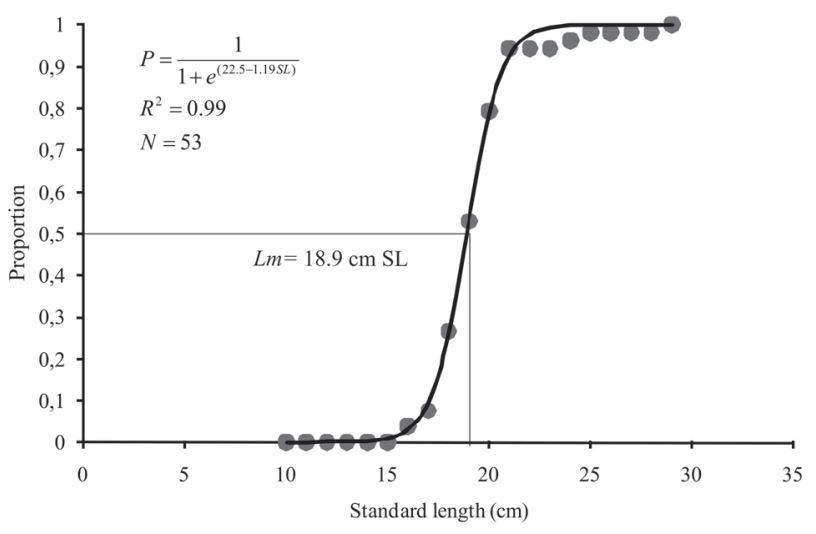

Fig. 7. Size at first maturity of the Sinaloa cichlid Cichlasoma beani in the Aguamilpa Reservoir in Nayarit, Mexico.
Our study initiates the groundwork for understanding the population structure and reproductive behavior of the Sinaloa cichlid. According to the reproductive information now available for $C$. beani and the other species of commercial importance in the reservoir, authorities and managers need to implement a management plan that protects the population, including a minimum legal size and a period prohibiting fishing. Additionally, it is important to inspect the construction of fishing gear used in the reservoir. We find evidence that the official prohibited fishing period established in for the Aguamilpa Reservoir (March to May) does not guarantee protection for $C$. beani population as a sustainable resource, because the size at first maturity should be considered in fisheries regulations.

\section{Acknowledgments}

Javier Marcial de Jesús Ruiz Velazco Arce, José Iván Velázquez Abunader and Jorge Saúl Ramírez Pérez are CONACYT, PIFI-IPN fellows. Jorge Saul Ramirez Perez is a recipient of a fellowship from the Programa de Doctores Jovenes of the Universidad Autonoma de Sinaloa. We thank the Government of the State of Nayarit, Mexico for partial financial support for this project.

\section{Literature Cited}

Admassu, D. \& J. M. Casselman. 2000. Otolith age determination for adult tilapia, Oreochromis niloticus L. from Lake Awassa (Ethiopian Rift Valley) by interpreting biannuli and differentiating biannual recruitment. Hydrobiologia, 418: 15-24.

Aguirre-Villaseñor, H., H. E. Morales-Bojórquez, R. E. MoránAngulo, J. Madrid-Vera \& M.C. Valdez-Pineda. 2006. Biological indicators for the Pacific sierra (Scomberomorus sierra) fishery in the southern Gulf of California, Mexico. Ciencias Marinas, 32: 471-484.

Balirwa, J. S. 1992. The evolution of the fishery of Oreochromis niloticus (Pisces: Cichlidae) in Lake Victoria. Hydrobiologia, 232: 85-89.

Biotecs, S. 1990. Determinación del potencial acuícola de los embalses epicontinentales mayores de 10000 hectáreas y nivel de aprovechamiento. Presa Miguel Alemán “Temazcal”. Informe Final Pesca, Mexico City.

Booth, A. J. \& G. S. Merron. 1996. The age and growth of the greenhead tilapia Oreochromis macrochir (Pisces: Cichlidae) from the Okavango Delta, Botswana. Hydrobiologia, 321: 29-34.

Bwanika, G. N., D. J. Murie \& L. J. Chapman. 2007. Comparative age and growth of Nile tilapia (Oreochromis niloticus L.) in lakes Nabugabo and Wamala, Uganda. Hydrobiologia, 589: 287-301.

Caskey, L. L., R. R. Riedel, B. Costa-Pierce, J. Butler \& S. H. Hurlbert. 2007. Population dynamics, distribution, and growth rate of tilapia (Oreochromis mossambicus) in the Salton Sea, California, with notes on bairdiella (Bairdiella icistia) and orangemouth corvine (Cynoscion xanthulus). Hydrobiologia, 576: $185-203$.

DOF. 2000. Norma Oficial Mexicana NOM-026-PESC-1999, que establece regulaciones para el aprovechamiento de los recursos pesqueros en el embalse de Aguamilpa, ubicado en el estado de Nayarit. Diario Oficial de la Federación, 9 February 2000. 
DOF. 2007. Acuerdo por el que se establece veda temporal para la captura de todas las especies de peces en aguas de jurisdicción federal del embalse de la presa Aguamilpa, ubicada en el Estado de Nayarit. Diario Oficial de la Federación, 1 March 2007.

Duponchelle, F., P. Cecchi, D. Corbin, J. Nuñez \& M. Legendere. 1999. Spawning season variations of female Nile tilapia, Oreochromis niloticus, from man-made lakes of Cote d'Ivoire. Environmental Biology of Fishes, 56: 375-387.

Faunce, C. H., H. M. Patterson \& J. J. Lorenz. 2002. Age, growth, and mortality of the Mayan cichlid (Cichlasoma urophthalmus) from the southeastern Everglades. Fishery Bulletin, 100: 42-50.

Fonticiella, D. W. 2000. Peso estandar de la tilapia (Orechromis aureus Steindachner) en Cuba. Revista de Producción Animal, 12: 5-12.

Fournier, D., J. Siber, J. Majkowski \& J. Hampton. 1990. MULTIFAN, a likelihood-based method for estimating growth parameters and age composition from multiple length frequency data sets illustrated by using data for southern bluefin tuna (Thunnus maccoyii). Canadian Journal of Fisheries and Aquatic Sciences, 47: 301-317.

Frota, L. Q., P. A. S. Costa, B. C. Braga. 2004. Length-weight relationships of marine fishes from the Central Brazilian Coast. NAGA, 27: 20-26.

Fryer, G. 1972. Conservation of the great lakes of East Africa: A lesson and a warning. Biological Conservation, 4: 256-262.

Getabu, A. 1992. Growth parameters and total mortality in Oreochromis niloticus (Linnaeus) from Nyanza Gulf, Lake Victoria. Hydrobiologia, 232: 91-97.

Gómez-Márquez, J. L; B. Peña-Mendoza, I. H. Salgado-Ugarte \& J. L. Arredondo-Figueroa. 2008. Age and growth of the tilapia, Oreochromis niloticus (Perciformes: Cichlidae) from a tropical shallow lake in Mexico. Revista de Biología Tropical, 56: 875-884.

Gómez-Marquez, J. L.; B. Peña-Mendoza, I. H. Salgado-Ugarte \& M. Guzmán-Arroyo. 2003. Reproductive aspects of Oreochromis niloticus (Perciformes: Cichlidae) at Coatetelco lake, Morelos, Mexico. Revista de Biología Tropical, 51: 221-228.

Haddon, M. 2001. Modelling and Quantitative Methods in Fisheries. Chapman \& Hall, Boca Raton, FL.

Ibáñez, A. L., 2004. Impact of the timing of stocking on growth and allometric index in aquaculture-based fisheries. Fisheries Management and Ecology, 11: 81-87.

Jiménez-Badillo, L. 2004. Application of holistic and analytical models for the management of tilapia fisheries in reservoir. Hidrobiológica, 14: 61-68.

Khallaf, E. A.; M. Galal \& M. Authman. 2003. The biology of Oreochormis niloticus in a polluted canal. Ecotoxicology, 12: 405-416.

Komalafe, O. O. \& G. A. O. Arawomo. 2007. Reproductive strategy of Oreochromis niloticus (Pisces: Cichlidae) in Opa Reservoir, Ile-Ife, Nigeria. Revista de Biología Tropical, 55: 595-602.

Le Cren, E. D. 1951. The lenght-weight relationship and seasonal cycle in gonad weight and condition in the perch (Perca fluviatilis). Journal of Animal Ecology, 20: 201-219.
Luna-Figueroa, J. \& J. Figueroa-Torres. 1999. La mojarra criolla de la subcuenca del río Amacuzac. Especies, 8: 25-27.

Miller, R.R. 1966. Geographical distribution of Central American freshwater fisheries. Copeia, 1996: 773-802.

Murphy, B. R., D. Willis \& T. A. Springer. 1991. The relative weight index in fisheries management: Status and needs. Fisheries, 16: 30-38.

Nikolsky, G. V. 1963. The Ecology of Fishes. Academic Press, London.

Orbe-Mendoza, A. A., D. Hernández-Montaño, J. Acevedo-García \& M. Guzman-Arroyo. 2002. Presa Aguamilpa, Nayarit, México. In G. de la Lanza-Espino \& J. L. García-Calderón (Eds). Lagos y Presas de México, Compiladores. AGT Editores, Mexico City, 402-420.

Peña-Messina, E., R. Tapia-Varela, J. I. Velázquez-Abunader, A. A. Orbe-Mendoza \& J. M. Ruiz Velazco-Arce. 2010. Growth, mortality and reproduction of the blue tilapia Oreochromis aureus (Perciformes: Cichlidae) in the Aguamilpa Resevoir, Mexico. Revista de Biología Tropical, 58: 1577-1586.

Pérez-Velázquez, P. A., P. Ulloa-Ramírez \& J. L. Patiño-Valencia. 2005. Diagnóstico de la pesquería comercial de escama en la Presa Hidroeléctrica Aguamilpa, Nayarit. Centro Regional de Investigación Pesquera. Instituto Nacional de Pesca. Bahía de Banderas, Nayarit, México, Mexico.

Ramos-Cruz, S. 1995. Reproducción y crecimiento de la mojarra tilapia (Oreochromis aureus) en la presa Benito Juárez, Oaxaca, México en 1993. INP-SEMARNAP Ciencia Pesquera, 11: 54-61.

Rangel-Peraza, J. G., J. De Anda, F. González-Farías \& D. Erickson. 2009. Statistical assessment of water quality seasonality in large tropical reservoirs. Lakes and Reservoir: Research \& Management, 14: 315-323.

Ricker, W. E. 1975. Computation and interpretation of biological statistics of fish populations. Bulletin of the Fisheries Research Board of Canada, 191: 300-382.

Rojas Carrillo, P. M. 2006. Reproductive aspects of "Charal prieto" Chirostoma attenuatum (Meek, 1902) of Lake Pátzcuaro, Michoacan. New topics on atherinopsids of México. Hidrobiológica, 16: 1-9.

SAGARPA. 2006. Presa de Aguamilpa, Nayarit. Carta Nacional Pesquera. Diario Oficial de la Federación, 25 August 2006.

Sparre, P. \& S. C. Venema. 1997. Introduction to tropical fish stock assessment. Part 1. FAO Fisheries Technical Paper. No. 306.2, Rome.

Sokal, R. \& J. Rohlf. 1979. Biometry: The Principles and Practice of Statistics in Biological Research. Blume Editions, San Francisco.

Wantzen, K. M., K. O. Rothhaupt, M. Mortl, M. Cantonati, L. G. Tóth \& P. Fisher. 2008. Ecological effects of water-level fluctuations in lakes: an urgent issue. Hydrobiologia, 613: 1-4.

Zar, H. J. 2010. Biostatistical Analysis, 5th ed. Prentice-Hall, Upper Saddle River, NJ.

Submitted June 16, 2010

Resubmitted April 14, 2011

Accepted June 28, 2011

Published September 16, 2011 